\title{
Análise de DNA em medicina legal, banco de dados e controle de qualidade
}

\author{
DNA analysis in forensic medicine, \\ data bank and quality control
}

Edna Sadayo Miazato Iwamura(1), Daniel Romero Muñoz ${ }^{(2)}$

Iwamura ESM; Muñoz DR. Análise de DNA em medicina legal, banco de dados e controle de qualidade. Saúde, Ética \& Justiça, São Paulo. 2003;8(1/2):13-7.

RESUMO: As análises forenses com finalidade identificatória têm sido utilizadas com considerável sucesso nos últimos anos, graças aos acelerado avanço das técnicas de biologia molecular e métodos de tipagem de DNA. Os autores, após descrevem a rápida evolução dessas técnicas e a criação de bancos de dados DNA em alguns países, discutem a necessidade de normas, padronização, o controle de qualidade e os cuidados na coleta e preservação das amostras biológicas, para a adequada utilização dessa tipagem de DNA, bem como as perspectivas para o Brasil nesse cenário de avanço tecnológico. Abordam, também, os aspectos bioéticos que devem ser considerados na utilização dessa tecnologia.

DESCRITORES: Antropologia forense. DNA. Bases de dados factuais. Brasil.

\section{INTRODUÇÃO}

A aplicação da tecnologia do DNA em investigações forenses cresceu rapidamente nos últimos 15 anos $^{1-9}$. Entretanto, as evidências de DNA que não são apropriadamente coletadas, documentadas, reconhecidas e preservadas podem ser invalidadas numa investigação criminal. Portanto, a coleta e preservação dessas amostras precisam ser garantidas ou a comunidade forense não será capaz de usar essa notável tecnologia para o interesse da justiça ${ }^{10}$.

As maiores fontes produtoras de amostras de

(1) Doutora em Ciências pela Faculdade de Medicina da USP, Especialização em Bioética pela FMUSP, Bióloga do Depto. de Medicina Legal, Ética Médica, Medicina Social e do Trabalho da Faculdade de Medicina da Universidade de São Paulo.

(2) Professor de Medicina Legal e Bioética do Depto. de Medicina Legal, Ética Médica, Medicina Social e do Trabalho da Faculdade de Medicina da Universidade de São Paulo.

Endereço para correspondência: Edna Sadayo Miazato Iwamura. Rua Teodoro Sampaio, 115, Cerqueira César, 05405-000 São Paulo, SP. e-mail: eiwamura @usp.br 
DNA são o sangue, o líquido seminal, a medula óssea, o cérebro, os músculos, a pele, a polpa dentária e manchas secas de sangue em tecido ou outra superfície ${ }^{10,11}$. Tais amostras, quando em boas condições, devem conter células nucleadas (DNAn) ou DNA mitocondrial (DNAmt) para serem usadas na identificação forense. Células nucleadas podem ser encontradas na saliva ou urina. Cabelos de queda natural e ossos de exumados também são outras fontes de DNA, porém degradados ${ }^{10,12}$. Ainda tecidos orgânicos não putrefeitos, fixados em formol e embebidos em parafina, podem conter DNA não degradado.

O espaço físico, especialmente em laboratórios de análise forense, deve ser levado em consideração. Consideremos os procedimentos de fluxo de trabaIho nos testes de DNA forense baseados na amplificação pela PCR (Polimerase Chain Reaction), que exigem: o local onde se extrai o DNA, local onde se realiza a quantificação e o protocolo de preparação da PCR, assim como a área e o tempo separados para o processo de amplificação, cuidados na manipulação de materiais, armazenamento das amostras-evidência, extratos de DNA e produtos de $\mathrm{PCR}^{3}$.

O que determina a escolha dos kits de amplificação de STRs - marcadores conhecidos como repetições curtas em seqúência (Short Tandem Repeats) de DNA - é a compatibilidade dos corantes da seqüência iniciadora (primers) com o laser do equipamento e o conjunto de filtros. Assim, o analisador genético $310 \mathrm{ABI}$ Prism $\AA$ e 0 Seqüenciador de DNA 377 ABI Prism $\AA$ (Applied Biosystems, Foster City, CA, USA) podem ser usados com o ABI Ampf/STR ${ }^{\text {TM }}$ de nove-loci Profile Plus $^{\mathrm{TM}}$ e o ABI Ampf/STR ${ }^{\mathrm{TM}}$ de sete-loci COfiler ${ }^{\mathrm{TM}}$ (Applied Biosystems), ou o GenePrint ${ }^{\circledR}$ dezesseisloci PowerPlex 16 amplification (Promega Corporation, Madison, WI, USA). O scanner fluorescente Hitachi FMBIO ${ }^{\text {II }}$ (Hitachi, Alameda, CA, USA) é usado com o GenePrint $\circledast$ PowerPlex ${ }^{\mathrm{TM}} 1.1$ de oito-loci e o GenePrint ${ }^{\circledR}$ PowerPlex ${ }^{\mathrm{TM}} 2.1$ de nove-loci (Promega Corporation) ${ }^{3,13}$.

Para avaliar o desempenho de sistemas de STRs, multiplex (3 ou 4 loci numa mesma reação) e megaplex (16 loci numa mesma reação), foram utilizadas amostras de extratos de DNA de ossos antigos e de dentes de 8 a 50 anos. Os sistemas Ampf/STRprofiler ${ }^{\mathrm{TM}} \mathrm{kit}$, Ampf/STR Profiler Plus ${ }^{\mathrm{TM}} \mathrm{kit}^{\mathrm{m}}$, Ampf/STRCOfiler' ${ }^{\mathrm{TM}}$ Kit e o sistema PowerPlex ${ }^{\mathrm{TM}} 16$ mostraram ser sistemas de amplificação de multiplex de STRs muito sensíveis que puderam ser usados com sucesso mesmo quando não havia DNA humano detectável no processo de quantificação ${ }^{14}$.

$\mathrm{Na}$ determinação de sexo o locus da amelogenina que, por coincidência, é o gene para a polpa dentária, mostra uma variação de comprimento do DNA entre os sexos. A forma feminina do gene contém uma deleção de 6 pares de bases e produz um fragmento menor quando amplificado pela PCR. Quando analisados, o indivíduo do sexo feminino, com dois cromossomos $X$, irá mostrar uma única banda enquanto o do sexo masculino, duas bandas, uma equivalente ao cromossomo $\mathrm{X}$ e outra equivalente ao cromossomo $\mathrm{Y}^{2}$.

Os produtos de amplificação da PCR, específicos do cromossomo X e Y, são curtos, 106/ 112 ou 212/218 pares de bases, oferecendo uma vantagem com relação às amostras de DNA degradadas ou quando quantidades limitadas de material estão disponíveis ${ }^{15,16}$.

O reconhecimento da necessidade de critérios e normas de tipagem de DNA dentro da comunidade forense nos Estados Unidos resultou na formação de um grupo nacional de cientistas forenses no final de 1980 chamado TWGDAM (Technical Working Group on DNA Analysis Methods). Esse grupo publicou uma série de normas para a tipagem de DNA forense, incluindo o roteiro de 1991 e 1995 (Guidelines for Quality Assurance Program for DNA Analysis 1991 e 1995) 17,18 . Utilizando o roteiro da TWGDAM foi implementado em outubro de 1998 o roteiro nacional de testes de DNA forense em laboratórios públicos, também conhecido como padrões do FBI (Federal Bureau of Investigation Standards) ou padrões nacionais, com a finalidade de se obter certificação/credenciamento ${ }^{3}$. Esses padrões incluem programas de testes de DNA interno, visando à segurança na qualidade, organização e administração, instalações de pessoal, controles das amostras-evidência, validação dos métodos do laboratório, procedimentos analíticos, calibração e manutenção de dados, testes de proficiência, ações corretivas, balanços e padrões dos fornecedores ${ }^{19}$.

A formação do Grupo de Perfil do DNA Europeu (EDNAP - European DNA Profiling Group) teve início em 1989 como uma associação informal de laboratórios europeus e organizações da polícia e 
institutos universitários que realizavam trabalhos forenses. Esse grupo representa a Comunidade Européia, assim como os países do Leste Europeu. Seu principal objetivo é a padronização da tipagem do DNA, realizando exercícios entre os membros do grupo, para alcançar a comparabilidade de resultados de tipagem ${ }^{20}$. Além do EDNAP, acima citado, há o Grupo Espanhol e Português (GEP) da Sociedade Internacional de Hemogenética Forense ${ }^{21}$.

No Brasil, temos representantes no Grupo Ibero-Americano de Trabalho em Análises do DNA (GITAD), criado em 1997 pelos irmãos Miguel e José Lorente (Espanha) $)^{21,22,23}$.

Em abril de 1999, a Sociedade Brasileira de Medicina Legal editou, como um primeiro exercício, um "caderno de intenções em testes de paternidade", com normas de conduta, aspectos de como devem ser os laboratórios, a identificação, coleta de espécimes e documentação, cálculos e relatórios ${ }^{24}$.

Considerando que, atualmente, todos os estados da federação já possuem laboratórios para análise de vínculo genético (Institutos de Criminalística, laboratórios de Universidades ou laboratórios particulares ${ }^{25}$, no futuro próximo é possível que esse "Caderno de Intenções" transforme-se num verdadeiro "Código de Normas" e se possa ter, para o Brasil, um padrão próprio, associado a um Controle de Qualidade Nacional.

\section{DNA e banco de dados}

O FBI (The federal Bureau of Investigation), agência americana de investigação, tem sido líder no desenvolvimento de tecnologias para genotipagem de DNA para uso na identificação de criminosos. Em 1997, a Divisão de Ciências Forenses do FBI selecionou 13 loci de STRs que iriam constituir o banco de dados de indivíduos condenados americano, denominando-o de CODIS (Combined DNA Index System). Os treze loci que fazem parte desse sistema são: vWA, FGA, D8S1179, D21S11, D18S51, D13S317, D7S820, D16S539, D3S1358, D5S818, TH01, TPOX e CSF1PO. Nas perícias forenses criminais é realizada uma comparação dos resultados obtidos com a tipagem do DNA de uma evidência biológica retirada da cena de um crime com a tipagem do DNA de um suspeito e/ou da própria vítima. Ocorrendo a com- binação genotípica das duas amostras nos 13 loci do CODIS há uma confirmação de que essas amostras são provenientes do mesmo indivíduo ${ }^{26}$. Atualmente, a análise do DNAmt também está incluso no sistema CODIS, USA ${ }^{23}$.

Os avanços nos programas de DNA forense, seguramente, têm acompanhado o desenvolvimento de equipamentos e dos kits de tipagem de DNA. Assim, os laboratórios forenses vêm rapidamente se adaptando e substituindo os marcadores genéticos e seus respectivos instrumentos de análise. Muitas vezes, esses laboratórios necessitam de mudanças drásticas, como a automação, quando o objetivo é analisar 10.000 a 20.000 amostras por ano, com a máxima eficiência e qualidade, com custos baixos e com o mínimo de tempo de resposta ${ }^{27}$. Nos Estados Unidos, quando a Divisão de Ciências Forenses iniciou a substituição do Banco de Dados de tecnologia de RFLP pela tecnologia de STRs, ocorria uma média de um acerto em um total de 2900 amostras de acusados condenados que entraram no Banco de Dados. Entretanto, em 31 de dezembro de 2000, ocorria uma média de um acerto no total de 700 amostras que entraram no Banco de Dados, aumentando-se a eficiência na ordem de quatro vezes ${ }^{26}$.

Em 1999, a Espanha demonstrou pioneirismo ao implantar oficialmente um programa para tentar identificar cadáveres e restos humanos que não puderam ser identificados pelo uso dos métodos forenses tradicionais. Esse programa foi chamado de "Programa Phoenix", onde são gerados dois bancos de dados de DNAmt independentes, que podem automaticamente, comparar e cruzar seqüências similares ou idênticas. Um deles é o Banco de Dados Referência, com seqüências de DNAmt de parentes maternos das pessoas desaparecidas, que fornecem amostras de células de raspado bucal, voluntariamente; o outro é o Banco de Dados Questionado, obtido de DNAmt de restos e cadáveres de indivíduos desconhecidos ${ }^{22,23}$.

Na lugoslávia, como resultado dos conflitos da última década, cerca de 30.000 pessoas estão desaparecidas. Em 2000, foi estabelecido formalmente um programa da Comissão Internacional de Pessoas Desaparecidas (ICMP - International Commission of Missing Persons), graças à colaboração de várias corporações governamentais $e$ privadas, numa tentativa de realizar a identificação 
humana através de uma rede com a aliança política, centros de acesso às famílias e laboratórios de DNA em toda a antiga lugoslávia. Seguindo o Programa DNA, os laboratórios de DNA da Bósnia-Herzegovina $(\mathrm{BH})$, Saravejo e Banja Luka têm-se dedicado em larga escala à tipagem de sangue e se equipado com os sistemas STR multiplex e DNAmt em dot-blot, desenvolvido pela Roche ${ }^{28}$.

A identificação de restos humanos de pessoas desaparecidas representa um problema crescente, tanto em países da União Européia quanto da América Latina ${ }^{23 .}$

Em dezembro de 1995, o presidente Fernando Henrique Cardoso sancionou a Lei 9.140, dispondo sobre "o reconhecimento das pessoas desaparecidas em razão de participação ou acusação de participação, em atividades políticas, no período de 2 de setembro de 1961 a 15 de agosto de 1979"29,30.

Grandes e relevantes esforços tem sido continuamente realizados para identificar cadáveres e restos humanos, após guerras, problemas sócios políticos, desastres de massa e por causa da própria dinâmica das sociedades modernas. Em muitos casos, o uso da tipagem de DNA pode oferecer uma resposta definitiva para a identificação de vítimas e pessoas desaparecidas ${ }^{31}$.

Por outro lado, simultaneamente aos avanços tecnológicos na ciência forense, a geração de banco de dados, pode ser vista por alguns como "temerosas para a sociedade".

No Brasil, a exemplo da Espanha, uma possibilidade da geração de banco de dados, que não compromete os direitos individuais e sociais, é a doação voluntária de amostras biológicas de familiares de pessoas desaparecidas. As amostras doadas voluntariamente, "após consentimento informado", gerariam um banco de dados "civil" para interesse dos próprios familiares de desaparecidos. Após 30 anos de espera, para alguns familiares, a solução para a identificação de restos que podem pertencer a um desses desaparecidos seria a criação de um programa de banco de dados de DNA estruturados. No entanto, para que essa ferramenta tenha o seu uso validado e garantido é necessário que se tome os devidos cuidados nos procedimentos de controle de qualidade e nos preceitos éticos.

Com a aplicação crescente dessa tecnologia da análise do DNA, torna-se imperativa a criação de programas nacionais e a cooperação internacional com países como a Espanha (GITAD), Inglaterra (EDNAP) e os Estados Unidos (Armed Forces e FBI) nesse esforço de identificação de pessoas desaparecidas.

Iwamura ESM, Muñoz DR. DNA analysis in forensic medicine, data bank and quality control. Saúde, Ética \& Justiça, São Paulo. 2003;8(1/2):13-7.

\begin{abstract}
S: In the last years, with the development of the molecular biology and the DNA typing methods, forensic analysis have been used world wide to solve identity issues with considerable success. The authors describe the fast evolution of these techniques, the creation of data bank in some countries, discusses the need of rules and standard procedures of collection, preservation of the biological evidence samples and the quality control for adequate utilisation of this DNA typing analysis, as well as the perspectives for Brazil in this technological advanced scenario. The procedures of quality control and bioethics are emphasized to garantee and validate the use of this technique.
\end{abstract}

KEY WORDS: Forensic anthropology. DNA. Databases, factual. Brazil.

\title{
REFERÊNCIAS
}

1. Jeffreys AJ, Brookfield JFY, Semeonoff R. Positive identification of an immigration test-case using human DNA fingerprints. Nature. 1985;317:818-9.
2. Inman K, Ruddin N. An introduction to forensic DNA analysis. Boca Raton: CRC Press; 1997.

3. Crouse CA. Implementation of forensic DNA analysis 
on casework evidence at the Palm Beach County Sheriff's office crime laboratory: historical perspective. Croat Med J. 2001;42:247-51.

4. Chakraborty R, Stivers DN, Su B, Zhong T.Budowle B. The utility of short tandem repeat loci beyond human identification: implications for development of new DNA typing systems. Electrophoresis. 1999;20:1682-96.

5. Short Tandem Repeat DNA Internet Database. [cited: 2002 Nov.] Disponível em: http://www.cstl.nist.gov./ biotech/strbase/.

6. Anderson S, Bankier AT, Barrell BG, Bruij MHL, Coulson AR, Douin J, et al. Sequence and organization of the human mitochondrial genome. Nature. 1981;290:457-65.

7. Henke J, Henke L, Chatthopadhyay P, Kayser M, Dülmer $M$, Cleef $S$, et al. Application on $Y$ chromosomal STR Haplotypes to forensic genetics. Croat Med J. 2001;42:292-7.

8. Gill P, Brenner C, Brinkmann B, Budowle B, Carracedo $A$, Jobling MA, et al. DNA Commission of the International Society of Forensic Genetics: recommendations on forensic analysis using $Y$ chromosome STRs. Forensic Sci Int. 2001;124:5-10.

9. Bosch E, Lee AC, Calafell F, Arroyo E, Henneman P, kniff $P$, et al. High resolution y chromosome typing: 19 STRs amplified in the three multiplex reactions. Forensic Sci Int. 2002;125:42-51.

10. Lee HC.; Ladd C. Preservation and Collection of Biological Evidence. Croat Med J. 2001;42:225-8.

11. Soares-Vieira JA, Muñoz DR, I wamura ESM, Billerbeck AEC. Analysis of DNA in minute volumes of blood from stains and crusts. Am J Forensic Med Pathol. 2001;22(3):308-12.

12. Iwamura ESM. Análise de DNA em osso humano: estudo qualitativo da microestrutura do osso compacto [tese]. São Paulo: Faculdade de Medicina, Universidade de São Paulo; 2002.

13. Tomsey CS, Kurtz $M$, Kist $F$, Hockensmith $M$, Call $P$. Comparison of PowerPlex ${ }^{\mathrm{TM}} 16$, PowerPlex 1.1/2.1 ${ }^{\mathrm{TM}}$, and $A B I$ Ampf/STR Profiler Plus тM /CofilerTM for forensic use. Croat Med J. 2001;42:239-43.

14. Alonso A, Andenovic S, Martin P, Sutlovic D, Erceg I, Huffine $E$,et al DNA typing from skeletal remains evaluation of multiplex and megaplex STR systems on DNA isolated from bone and teeth samples. Croat Med J. 2001;42:260-6.

15. Pouchkarev VP, Shved EF, Novikov PI. Sex determination of forensic samples by polymerase chain reaction of the amelogenin gene and analysis by capillary eletrophoresis with polymer matrix. Electrophoresis. 1998;19:76-9.

16. LaFountain M, Schwartz M, Cormier J, Buel E. Validation of capillary electrophoresis for analysis of the $\mathrm{X}-\mathrm{Y}$ homologous amelogenin gene. J Forensic Sci. 1998;43:1188-94.
17. National Research Council. DNA technology in forensic science. Washington (DC): National Academy Press; 1992.

18. National Research Council. The evaluation of Forensic DNA evidence. Washington (DC): National Academy Press; 1996.

19. Conselho Nacional de Pesquisa. Comitê sobre Tecnologia do DNA na ciência forense / Conselho Nacional de Pesquisa. Comitê sobre Tecnologia do DNA na ciência forense, Conselho de Biologia, Comissão sobre Ciências da Vida. Tradução e revisão Francisco A. Moura Duarte ...[et al.]. Ribeirão Preto: FUNPEC-RP; 2001.

20. Shneider PM. Basic issues in forensic DNA typing. Forensic Sci Int. 1997;88:17-22.

21.Simas Filho, F. A prova na investigação de paternidade. 7a ed. rev. atual. Curitiba: Juruá Editora; 2001

22. Lorente JA, Entrada C, Alvarez C, Arce B Heinrichs B, Lorente M, Carrasco F, et al. Identification of missing persons: the Spanish "Phoenix" Program. Croat Med J. 2001;42:267-70.

23. Lorente JA, Entrala C, Alvarez JC, Lorente M, Arce $B$, Heinrich $B$, et al. Social benefits of non-criminal genetic databases: missing persons and human remains identification. Int $\mathrm{J}$ Legal Med. 2002;116:187-90.

24. Bydlowski SP, Moura Neto RS , Muñoz DR. Testes de paternidade através de DNA - recomendações para laboratórios. Brasil: SBML; 1999.

25. II Simpósio Internacional de Identificação Humana por DNA;2003 nov 27-28; Rio de Janeiro, Rio de Janeiro; Brasil.

26. Ban JD. Establishing a large DNA data bank using PowerPlex ${ }^{\mathrm{TM}} 1.1$ and 2.1 Systems. Croat Med J. 2001;42:256-9.

27. Steinlechner M, Parson W. Automation and high through put for a DNA database Laboratory development of a laboratory information Management system. Croat Med J. 2001; 42:252-5.

28. Huffine E.; Crews J, Kennedy B, Bomverger K, Zinbo A. Mass identification of persons missing from the break-up of the former Yugoslavia: structure, function, and role of the international commission on missing persons. Croat Med J. 2001;42:271-5.

29. Comissão de Familiares de Mortos e Desaparecidos Políticos. Disponível em: http://www.desaparecidos políticos.org.br/comissão.html.

30. Azambuja CIS. Comissão de Desaparecidos políticos.. Disponível em http://www.teruma.com.br/ desaparecidos.htm.

31. Iwamura ESM, Soares-Vieira JÁ, Muñoz DR. Analysis of DNA in bones for human identification. Rev. Hosp. Clin. Fac. Med. Univ. S. Paulo. 2004 (aceito para publicação em maio de 2004). 